\title{
Strategy for Competitive Advantage of Traditional Sunda Food
}

\author{
Dikdik Purwadisastra* and Indarta Priyana
}

\author{
Faculty of Economics and Business, Universitas Informatika dan Bisnis Indonesia, Bandung, Indonesia \\ *Corresponding author: dikdiknurtanio@unibi.ac.id
}

\begin{abstract}
The West Java millennial generation is considered to dislike Sundanese traditional food, this is due to several factors, this study aims to determine the right strategy to improve the competitiveness of Sundanese traditional food in their own area, the research method used is descriptive with a qualitative approach, the results of the study using a matrix IFAS and EFAS are known to have several strengths, opportunities but there are also weaknesses and threats which of course need to be improved by making taste innovations, increasing the ability of traditional Sundanese food processing experts and of course increasing competitiveness with international products that have flooded West Java.
\end{abstract}

Keywords: Competitive Advantage, Traditional Food

\section{INTRODUCTION}

The culinary industry in Bandung in the current era is quite promising, this is because Bandung is a city for shopping, both fashion and culinary. The food industry in Bandung is quite fast, which is marked by the emergence of various kinds of restaurants that offer various types of food and beverages, both modern and traditional West Java food.

Based on data from the Central Bureau of Statistics, the population of Bandung City in 2019 as many as three million residents with $60 \%$ of the Millennial generation with an age range between 17 - 38 years, this is certainly an economic potential for the food and beverage industry in Bandung City besides tourists who support the city's economy. Bandung.

In this study the authors further examine how traditional West Java food and drinks achieve competitive advantage in Bandung, which is a city with a high level of consumer intelligence, the millennial generation of Bandung City, based on the previous author's research data, about $66.7 \%$ know traditional Sundanese / West Java specialties. But it is unfortunate that the majority rarely and even never consume traditional food as much as $66.7 \%$, this is a problem in itself for traditional Sundanese food and drinks to maintain their existence.
SWOT Analysis is very important to see the extent to which measuring the extent to which the competitiveness of traditional Sundanese food and drinks with conventional or modern food and beverages, there are several factors that cause traditional Sundanese food to maintain its existence including social values or other meanings implied behind the taste, color, and the form of a food [1]. According to several previous studies there are some truly ironic phenomena, students have considered traditional food to be no longer attractive and students and the younger generation prefer modern food outlets [2].

\section{LITERATURE REVIEW}

Traditional food is food that shows the characteristics of an area and the values that exist in that value [3]. Food that has become a tradition and passed down from generation to generation is traditional food, attached to local traditions, giving rise to certain perceptual experiences with high nutritional value [4]. Traditional food is also always consumed from the past in an area, the dishes must be in accordance with human tastes, must not conflict with the religious beliefs of the local community, and of course it is made from local or local ingredients and spices, traditional food as a food product that is used to be eaten 
by ancestors to today's society [5]. Defines traditional food as food consumed by specific ethnic groups and regions, processed based on recipes that have been passed down from generation to generation [6].

Based on the explanation above, it can be concluded that the definition of traditional food is food that has the characteristics of a certain region or certain ethnicity which is consumed from generation to generation and becomes sacred on certain occasions if it does not consume the food.

Definition of Strategic Management is the science of the formulation, implementation and evaluation of crossfunctional decisions that allow organizations to achieve their goals [7]. while other opinions regarding Strategic Management is an art of science in terms of making (Formulating) , Implementation (Implementing), and evaluating (evaluating) decisions between functions that allow an organization to achieve its goals in the future [8]. Based on the above definition, strategic management is a system implemented by the company in the formulation, implementation and implementation of every company policy both in the short and long term and of course there must be harmony from the leadership to the employees at the lowest level so that the company's policies achieve their goals.

\section{METHODOLOGY}

The method used in this research is descriptive qualitative, why use qualitative descriptive because it is intended to collect actual and detailed information, identify problems, make comparisons or evaluations, determine what other people do in dealing with the same problem and learn from their experiences for make decisions in the future [9].

In this study the authors used a SWOT analysis in assessing and examining traditional West Java food and beverages in order to have competitiveness, there are several stages here, namely:

1. Make a general SWOT analysis

2. Creating the TOWS Matrix

3. Assessing problems from the TOWS matrix

4. Draw Solutions and Conclusions

\section{RESULTS AND DISCUSSION}

In this study, the authors used SWOT Analysis to analyze the current position of traditional West Javanese food. In the SWOT analysis, the analysis includes internal factors including strengths and weaknesses, in addition to internal factors, external factors also need to be analyzed. Includes Opportunity and Threat (Treat).

The following is a SWOT analysis regarding the potential of traditional West Java food in competition with international food, many restaurants in West Java.
1. Strength (Strengths)

a. Raw materials are easy to get

b. It has been introduced from generation to generation from parents, it is quite advantageous for the position of traditional food because it is well known

c. Many experts are used to making traditional Sundanese food

2. Weakness (Weakness)

a. Too confident with the familiar and familiar West Javanese traditional food in the community

b. Too conventional and monotonous taste

c. Insights and Innovations from experts

d. Equipment for processing food

e. A rigid and unclear Marketing Strategy

3. Opportunity

a. Central, Provincial and City / Regency Government Regulations in the development of MSMEs and domestic products, including traditional specialties

b. Prices tend to be cheaper than foreign food

c. The rapid development of the population of the West Java area has become a business potential for West Java traditional food entrepreneurs.

4. Threats (Treat)

a. Domestic and foreign competitors

b. Innovative flavors from competitors tailored to the tastes of the local community

c. The current competitive conditions in which the Asian Economic Community and AFTA force the Government to open opportunities for foreign products to enter and do business in Indonesia

d. Local traders like to sell foreign food, whose business potential is higher than traditional Sundanese food

e. Lack of marketing network

After determining the Strengths, Weaknesses, Opportunities and Threats of traditional West Java foods, now we weight them using the IFAS (Internal Factor Analysis) and EFAS (External Factor Analysis) matrices, which according to Rangkuti 2012, the weighting of IFAS and EFAS as follows:

1. Make the factors into strengths, weaknesses, opportunities and threats.

2. Rating ranging from 4-1 (strong to small strengths and opportunities) Weights 1-4 (Weakness and Threat is strongest to small)

3. Giving weights from 1.00 to 0.00 ranging from important to insignificant issues.

4. Perform multiplication between weight and rating to measure the extent to which traditional food companies react to internal and external problems [10].

Our first step is to analyze internal factors on the competitiveness of traditional Sundanese food as shown in the Table 1. 
Table 1 Analyze internal factors on the competitiveness of traditional Sundanese food as

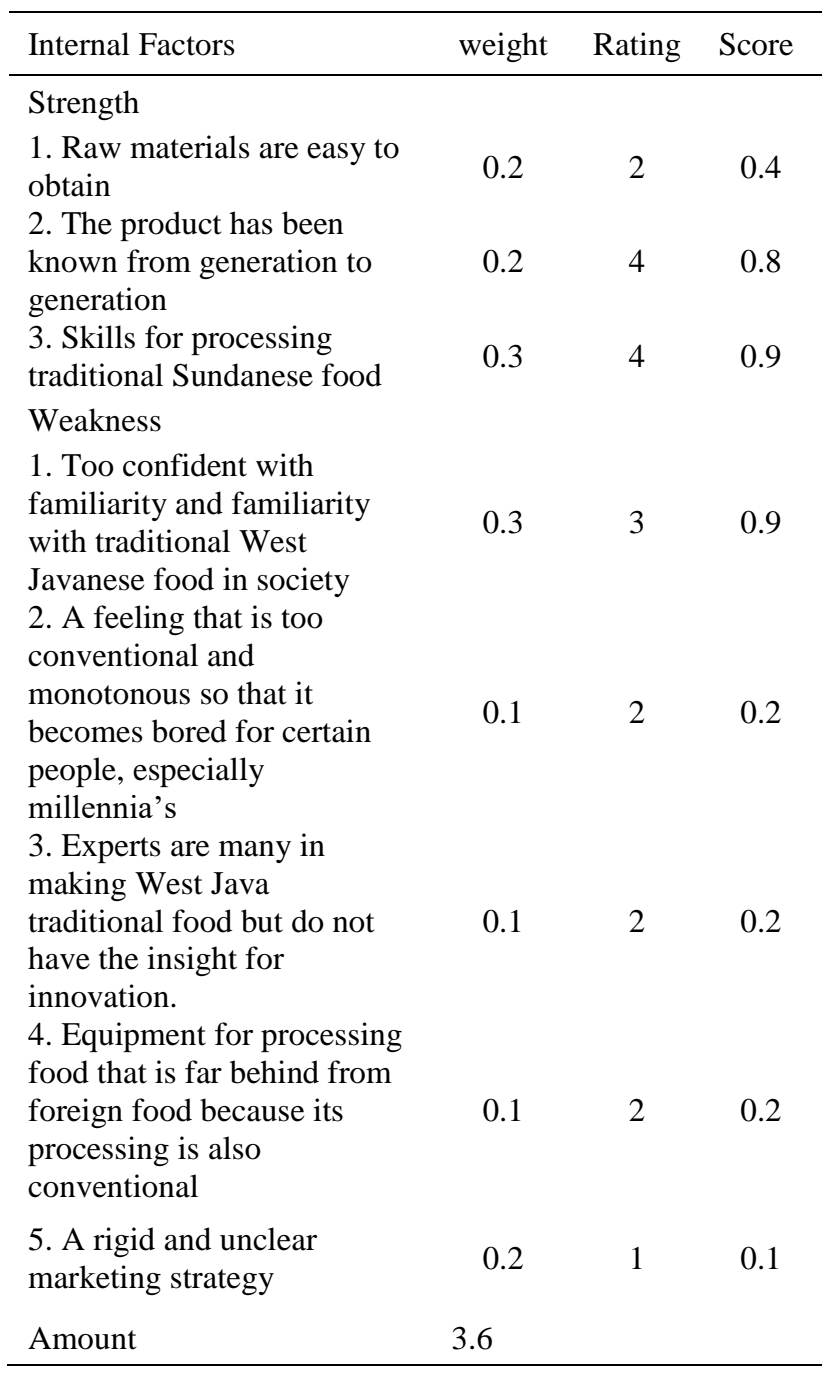

Based on the Table 1, it is known that the score of 3.6 is at a very important level to improve strategies to improve the competitiveness of traditional Sundanese food compared to foreign food, of course, you must maximize strength, especially the skills of traditional Sundanese food processing experts to innovate more in taste and reducing some of the existing weaknesses, including improving the taste that is too conventional so that food becomes boring, especially for the millennial generation. It is also hoped that marketing will not be too monotonous, must be more adaptable to the use of digital technology, and seek relationships from modern retailers so that by entering modern retailers, Sundanese traditional food becomes better known.
Table 2 analyze the external factors on the competitiveness of traditional Sundanese food as

\begin{tabular}{|c|c|c|c|}
\hline External Factors & weight & Rating & Score \\
\hline $\begin{array}{l}\text { Opportunity } \\
\text { 1. Central, Provincial and City / } \\
\text { Regency Government Regulations } \\
\text { in the development of MSMEs } \\
\text { and domestic products, including } \\
\text { traditional specialties }\end{array}$ & 0.2 & 3 & 0.6 \\
\hline $\begin{array}{l}\text { 2. Prices tend to be cheaper than } \\
\text { foreign food }\end{array}$ & 0.3 & 2 & 0.6 \\
\hline $\begin{array}{l}\text { 3. The rapid development of the } \\
\text { population of the West Java } \\
\text { region has become a business } \\
\text { potential for West Java traditional } \\
\text { food entrepreneurs. }\end{array}$ & 0.3 & 2 & 0.6 \\
\hline \multicolumn{4}{|l|}{ Threat } \\
\hline $\begin{array}{l}\text { Domestic and foreign competitors } \\
\text { 2. Innovative tastes from }\end{array}$ & 0.1 & 1 & 0.1 \\
\hline $\begin{array}{l}\text { competitors tailored to the tastes } \\
\text { of local communities }\end{array}$ & 0.2 & 2 & 0.4 \\
\hline $\begin{array}{l}\text { 3. Current competitive conditions } \\
\text { in which the Asian Economic } \\
\text { Community and AFTA force the } \\
\text { Government to open opportunities } \\
\text { for foreign products to enter and } \\
\text { do business in Indonesia }\end{array}$ & 0.1 & 1 & 0.1 \\
\hline $\begin{array}{l}\text { 4. Local traders like to sell } \\
\text { foreign food which has a higher } \\
\text { business potential than traditional } \\
\text { Sundanese food }\end{array}$ & 0.2 & 1 & 0.2 \\
\hline 5. Lack of marketing networks & 0.2 & 1 & 0.2 \\
\hline Amount & 2.6 & & \\
\hline
\end{tabular}

Based on data from Table 2, it is known that the EFAS matrix value is 2.6 at a fairly low value, here we must maximize opportunities such as government regulations must continue to encourage Micro, Small and Medium Enterprises to develop more with permit restrictions for both local and foreign entrepreneurs who sell products food from abroad, taking advantage of the rapid population of West Java as economic potential in the traditional Sundanese food business, especially the millennial generation, and must overcome potential threats, especially competitors outside West Java and abroad by improving product quality, improving service, seeing competitor innovations and of course strengthening marketing networks wider. 
After making SWOT and IFAS and EFAS matrices, a strategy is made for each of the existing points.

1. Strategy Strength-Opportunity (SO)

Sundanese traditional food culinary entrepreneurs must be able to maintain the availability of raw materials and improve the skills and knowledge of food-making experts and strengthen the relationship between the government and traditional Sundanese food entrepreneurs so that the Government also introduces traditional Sundanese food both in West Java and outside West Java, prices which can compete is an opportunity in itself and of course the economic potential of West Java with a large population is a promising promotion tool for traditional Sundanese food.

2. Weakness-Threats (WT) Strategy

Culinary entrepreneurs must always innovate in terms of taste that can be accepted by various parties, both natives of West Java, especially the millennial generation and outside of West Java society, why should taste innovate because the main competitor of traditional West Java food, its products have flooded various cities in West Java, both foreign food Provinces and foreign food, of course, traditional Sundanese food must be able to compete in addition to cheap prices, of course, the taste must innovate so that it can be accepted by various groups, especially the millennial generation.

3. Weakness-Opportunity (WO) Strategy

Culinary entrepreneurs are required to innovate to improve existing flavors, because with delicious and familiar tastes for various groups, with innovative products at affordable prices it will be increasingly in demand among the millennial generation, the Government must also play an important role in promoting traditional Sundanese food products.

4. Strengths -t hearts (WT) Strategy

Sundanese traditional food culinary entrepreneurs must utilize raw materials that are easily available and of course the experts must always be updated so that they continue to innovate to produce quality products at affordable prices.

\section{CONCLUSION}

Based on the results of existing research, it is known that the IFAS Matrix is at a score of 3.6 which is quite high, but it still has to make improvements by reducing existing weaknesses by maximizing existing strengths. But the EFAS matrix is at a score of 2.6, which means you really have to really make improvements, especially reduce the existing threats and take advantage of opportunities to win the competition for traditional Sundanese food, therefore a SWOT analysis strategy is applied where there are several strategies used both SO, WT, WO and ST.

\section{REFERENCES}

[1] N. N. Ramadhany, R. Iskandar, A. Sudono. An Analysis of The Existence Level of West Javanese Traditional Beverages as Sundanese Cultural Heritage. Gastronomy Tourism Journal, 7 (1) (2020) 20-32.

[2] M. Purnomo, E. Permana, A. Qosasi, A. F.Febrian, A. Miftahuddin. Entrepreneurial Orientation in Micro and Small Enterprises of Traditional Food Centers in Bandung, West Java. Binus Business Review, 10 (3) (2019) 167-174. DOI: https://doi.org/10.21512/bbr.v1 $0 \mathrm{i} 3.5611$

[3] P. Fernández-Ferrín, A. Calvo-Turrientes, B. Bande, M. Artaraz-Miñón, M. M. Galán-Ladero. The valuation and purchase of food products that combine local, regional and traditional features: The influence of consumer ethnocentrism. Food Quality and Preference, 64 (2018) 138-147. DOI: https://doi.org/10. 1016/j.foodqual.2017.09.015

[4] Muhilal. Traditional Food as a Source of Nutrient and Non-Nutritional Substances in Improving Individual and Community Health. National Workshop on the Efficacy of Traditional Food. Jakarta, 9-11 June 1995

[5] D. Suryadarma, A. Poesoro, S. Budiyati, M. Rosfadhila, A. Suryahadi. Traditional food traders in developing countries and competition from supermarkets: Evidence from Indonesia. Food Policy, 35 (1) (2010) 79-86. DOI: https://doi.org/10.10 16/j.foodpol.2009.11.002

[6] C. N. Rachmi, C. L. Hunter, M. Li, L. A. Baur. Food choices made by primary carers (mothers /grandmothers) in West Java, Indonesia. Appetite, 130 (2018) 84-92. DOI: https://doi.org/10.1016/j.appet.2018 .08 .005

[7] L. K. Shoemaker, B. Fischer. Creating a nursing strategic planning framework based on evidence. Nursing Clinics, 46 (1) (2011) 11-25. DOI: https://doi.org/10.1016/j.cnur.2010.10.007

[8] R. J. Baumgartner, R. Rauter. Strategic perspectives of corporate sustainability management to develop a sustainable organization. Journal of Cleaner Production, 140 (2017) 81-92. DOI: https://doi.org/10.1016/j.jcle pro.2016.04.146

[9] R. Alghamdi, M. Albloushi, E. Alzahrani, A. Aldawsari, S. Alyousef. Nursing education challenges from saudi nurse educators' and leaders' perspectives: A qualitative descriptive study. International journal of nursing education scholarship, 16 (1) (2019) 70-80. DOI: https://doi.org/10.1515/ijnes-2018-0027

[10] Rangkuti. Business and Investment Feasibility Study, Jakarta: Gramedia Pusataka Utama, 2012 